\title{
Characterization of bovine interleukin-2 stably expressed in HEK-293 cells
}

\author{
Shuya MITOMA ${ }^{1)}$, Heba M. EL-KHAIAT ${ }^{2)}$, Tomofumi UTO ${ }^{3)}$, Katsuaki SATO3), \\ Satoshi SEKIGUCHI ${ }^{1,4)}$ and Junzo NORIMINE ${ }^{1) *}$ \\ 1)Department of Veterinary Sciences, Faculty of Agriculture, University of Miyazaki, 1-1 Gakuen-Kibanadai-Nishi, \\ Miyazaki 889-2192, Japan \\ ${ }^{2)}$ Department of Animal Medicine, Faculty of Veterinary Medicine, Benha University, 13736 Moshtohor, Toukh, \\ Qalyubia, Egypt \\ 3)Division of Immunology, Department of Infectious Diseases, Faculty of Medicine, University of Miyazaki, \\ 5200 Kihara, Kiyotake, Miyazaki 889-1692, Japan \\ ${ }^{4)}$ Division of Prevention and Control for Animal Diseases, Center for Animal Disease Control, University of Miyazaki, \\ 1-1 Gakuen-Kibanadai-Nishi, Miyazaki 889-2192, Japan
}

J. Vet. Med. Sci.

83(1): 134-141, 2021

doi: 10.1292/jvms.20-0423

Received: 9 July 2020

Accepted: 29 October 2020

Advanced Epub:

11 November 2020
ABSTRACT. Interleukin 2 (IL-2) is a pleotropic cytokine and well-known as a T cell growth factor in immunology. It is now known to exert both immunostimulatory and immunosuppressive effects, optimizing immunological microenvironments for effector and regulatory $T$ cell responses. The immunomodulatory role of IL-2 is critical for deciding whether or not T cell responses against specific antigens result in protection. We have established a mammalian cell line (HEK-293) stably expressing bovine IL-2 (bolL-2) (designated as HEK-293/bolL-2), using the piggyBac transposon system. The concentration of recombinant bovine IL-2 (rbolL-2) in the culture supernatant of HEK293/bolL-2 reached $100 \mathrm{ng} / \mathrm{ml}$ on day 7 and showed similar proliferative activity to recombinant human IL-2 (rhulL-2) for bovine peripheral mononuclear blood cells. Although rhulL-2 has been often used to activate bovine $T$ cells, our results indicate that characteristics of the $T$ cell activation through rbolL-2 and hulL-2 appear slightly but significantly different. Interestingly, the rbolL-2/ anti-bolL-2 monoclonal antibody (C5) (rbolL-2/C5) complex strongly induced proliferation of bovine NKp $46^{+}$cells, natural killer (NK) cells, in vitro. This indicates that the rbolL-2/C5 complex could function as an IL-2 agonist specifically to increase the NK cell population, which in turn could enhance the activity of NK cells leading to protective immunity.

KEY WORDS: bovine interleukin-2, bovine interleukin-2 monoclonal antibody, stable expression

Interleukin-2 (IL-2) is the first cytokine cloned and biologically produced as a recombinant cytokine [1]. It has long been known as a $\mathrm{T}$ cell growth factor mainly secreted by $\mathrm{CD} 4^{+} \mathrm{T}$ cells that influence activities of $\mathrm{CD} 4^{+} \mathrm{T}, \mathrm{CD} 8^{+} \mathrm{T}, \gamma \delta \mathrm{T}, \mathrm{NK}$, and other cells such as innate lymphoid cells (ILCs) in autocrine and paracrine manners [2, 15, 29]. IL-2 is also used for cancer treatment, vaccine adjuvant, anti-viral therapy or T cell epitope mapping in human and mice [5, 15, 26, 28, 32]. The adjuvant effect of the bovine IL-2 (boIL-2) was also reported for Brucella abortus vaccines in cattle [34]. It was recently discovered that IL-2 can induce not only effector immune cells but also immune suppressive cells, such as regulatory $\mathrm{T}$ (Treg) cells. These contradictory functions depend on quantity and quality of interaction with its counterpart receptor, the IL-2 receptor (IL-2R), which consists of three chains: IL-2R $\alpha$ (CD25), IL-2R $\beta$ (CD122), and common (c $\gamma$ ) (CD132) chains [29]. Although IL-2R with high affinity consists of all three chains, the one with intermediate affinity is a heterodimer of IL-2R $\beta$ and $c \gamma$ chains. The functional intermediate-affinity receptors are expressed primarily on resting NK cells and $\mathrm{CD} 8^{+} \mathrm{T}$ cells, while the higt-affinity receptors are constitutively expressed on Treg cells. Both IL-2R $\beta$ and $c \gamma$ chains have activation signal motifs in their cytoplasmic domains, while the $\alpha$ chain does not have cytoplasmic activating nor inhibitory motifs and therefore does not mediate for signaling [23, 25].

Biologically active bovine IL-2 (boIL-2) was first purified from bovine peripheral blood mononuclear cells (PBMC) stimulated with the T cell mitogen concanavalin A (ConA) by Namen et al. and Brown et al. [9, 24]. Since IL-2 was immediately recognized to play an important role in protective immunity, production of biologically active recombinant bovine IL-2 (rboIL-2) was attempted for studying bovine immune systems. Since human IL-2 (huIL-2) became known to stimulate bovine lymphocytes, it has long been used for activating bovine PBMC or T cells, while several researchers also produced rboIL-2 using different expression systems. The rboIL-2 was first expressed in Escherichia coli and found biologically active for a bovine T cell line [9]. The 
rboIL-2 production in other systems includes yeast, baculovirus, and bovine herpes virus-1 expression systems [4, 19, 20, 27, 33]. Mammalian cell lines, such as $293 \mathrm{~T}$ or COS cells, have also been used to transiently express boIL-2 and stimulate bovine NKp46 cells $[8,30]$. These transient mammalian expression systems appeared superior over other systems because they have a high yield of rbolL-2 and, more importantly, can reserve original biological properties and stabilities by maintaining the native form of post-translational modification, $o$-glycosylation $[13,21,31]$. In addition, the culture supernatant can be readily used to assess the activities without generating toxic byproducts and/or recombinant vector virus contamination. The selective cell stimulation using the bioactivity of IL-2/anti-IL-2 antibody complex (IL-2C) is also known from the recent progress of IL-2 study [7]. Therefore, a recombinant IL-2 is extremely attractive for a variety of therapeutic applications.

In this study, we established a mammalian cell line, the HEK-293 cell line, that stably secretes boIL-2 in the culture supernatant. The supernatant containing boIL-2 can be readily used to stimulate IL-2-responsive immune cells. In fact, we have successfully used this rboIL-2 to propagate $\mathrm{CD} 4^{+} \mathrm{T}$ cells and identified several $\mathrm{CD} 4^{+} \mathrm{T}$ cell epitopes (data not shown). In addition, the rboIL-2 can selectively stimulate NKp $46^{+}$cell lineages when added as a complex with a monoclonal antibody (mAb) against boIL-2. These characteristics of the boIL-2 were presented in this work.

\section{MATERIALS AND METHODS}

\section{Animals}

Female Japanese Black cattle, aged 16 to 17 years old, maintained at the facility in the University of Miyazaki were used in this study. The results were derived from experiments on a 16-year old animal. All animals were confirmed free from bovine viral diarrhea virus and bovine leukemia virus. The experimental procedures and care of animals were in accordance with the guidelines approved by the Institutional Animal Care and Use Committee of the University of Miyazaki, Miyazaki, Japan.

\section{Cell preparation}

Fresh blood were collected from the Japanese Black cattle and the peripheral blood mononuclear cells (PBMCs) were isolated using Histopaque 1077 (Sigma Aldrich, St. Louis, MO, USA). These PBMCs were used for RNA extraction, carboxyfluorescein diacetate succinimidyl ester (CFSE) proliferation assay, or frozen at $-80^{\circ} \mathrm{C}$ in $10 \% \mathrm{DMSO} / \mathrm{FBS}$ for any additional experiments.

\section{$R N A$ extraction and cloning of bolL-2 gene in the piggyBac vector}

To amplify the boIL-2 gene, total RNA was extracted from bovine PBMCs using Trizol Reagent (Invitrogen, Carlsbad, CA, USA) and synthesized the first strand cDNA using iScript ${ }^{\mathrm{TM}}$ cDNA Synthesis Kit (Bio-Rad, Hercules, CA, USA) according to the manufacture instruction. The full length of boIL-2 cDNA was amplified using TaKaRa Ex Taq Hot Start Version (Takara Bio, Kusatsu, Japan). The primers used were as follows: boIL-2F, 5'-AAGGATCCACAATGTACAAGATACAACTCT-3' (forward) and boIL-2R, 5'-AAGCGGCCGCTCAAGTCATTGTTGAGTAGATG-3' (reverse). These primers were designed to include BamHI and NotI recognition sites, respectively, to clone the boIL-2 gene into the piggyBac vector, PB-CMV-MCS-EF1 $\alpha$-GreenPuro PiggyBac expression vector (System Biosciences, Palo Alto, CA, USA.), in correct direction for expression. The PCR condition was $94^{\circ} \mathrm{C}$ for $2 \mathrm{~min}, 35 \mathrm{cycles}$ of $94^{\circ} \mathrm{C}$ for $30 \mathrm{sec}, 57^{\circ} \mathrm{C}$ for $15 \mathrm{sec}$, and $72^{\circ} \mathrm{C}$ for $30 \mathrm{sec}$, with final extension of $72^{\circ} \mathrm{C}$ for $7 \mathrm{~min}$. The PCR amplicon was digested with BamHI and NotI (TOYOBO, Ltd., Osaka, Japan), electrophoresed, and purified with QIAquick gel extraction kit (QIAGEN, Hilden, Germany). The purified PCR amplicon was ligated into piggyBac vector plasmid DNA digested with the same restriction enzymes. The ligated product was introduced to One Shot TOP10 Chemically Competent E.coli (Life Technologies) by heat shock at $42^{\circ} \mathrm{C}$. After extraction of the plasmid DNA, the direction and sequence of the boIL-2 gene was confirmed by sequencing with BigDye terminator v3.1 (Applied Biosystems, Forster City, CA, USA).

\section{Establishment of HEK-293/boIL-2 cell line}

The constructed piggyBac expression vector (piggyBac/boIL-2) plasmid DNA was transfected to HEK-293 cells (Invitrogen) using Xfect ${ }^{\mathrm{TM}}$ Transfection Reagent (Takara Bio) according to the manufacturer's instruction. Briefly, $0.5 \mu \mathrm{g}$ of piggyBac/bolL-2 plasmid DNA and $0.5 \mu \mathrm{g}$ of Super PiggyBac Transposase Expression Vector (System Biosciences) were co-transfected into 50\% confluent HEK-293 cells in a 24-wells plate using $0.3 \mu 1$ of Xfect polymer. Four hours after transfection, culture medium was exchanged to fresh medium. Two days later, cells culture condition set up as the presence of $3 \mu \mathrm{g} / \mathrm{ml}$ puromycin and keep the presence of $3 \mu \mathrm{g} / \mathrm{ml}$ of puromycin for 13 passages to select the boIL-2 expression gene-transposed cells. The culture condition of boIL-2-transfected HEK-293 cells was in 10\% FBS (HyClone, South Logan, UT, USA) containing Dulbecco's Modified Eagle Medium (Sigma-Aldrich) with penicillin and streptomycin, and it was maintained by passage every 5-6 days. To establish a boIL-2-expressing clonal cell line, the cells were plated on the 96-wells flat plate in 0.5 cell/well (as a calculated number). After confirming a single cell growing in a single well, grown clonal cells were transferred to a $25 \mathrm{~cm}^{2}$ flask after 2 passages. The cells were also confirmed for their expression of GFP co-expressed with the boIL-2 using fluorescent microscope.

\section{Western blotting of rboIL-2 in the culture supernatant}

To confirm rboIL-2 expression in the culture supernatant, Western blotting was performed. The fifth day culture supernatant of HEK-293 or HEK-293/boIL-2 was loaded after sample buffer treatment, electrophoresed, and transferred to PVDF-membrane (GE healthcare Life Sciences, Marlborough, MA, USA). Two $\mu \mathrm{g} / \mathrm{ml}$ of anti-boIL-2 mAb (C5, IgG2a; Cloud-Clone Corp., Katy, TX, USA) was used as a primary antibody and $0.2 \mu \mathrm{g} / \mathrm{ml}$ of goat anti-mouse IgG HRP-conjugated polyclonal antibody (Abcam, 
Cambridge, UK) was used as a secondary antibody. Subsequently, the positive bands were visualized with ChemiDoc ${ }^{\mathrm{TM}}$ Touch Imaging System (Bio-Rad) after adding the SuperSignal ${ }^{\mathrm{TM}}$ West Dura Extended Duration Substrate (Thermo Scientific, Rockford, IL, USA).

\section{Quantitation of rboIL-2 in culture medium by ELISA}

To quantitate the rboIL-2 expressed in the culture supernatant of the HEK-293/boIL-2 and HEK-293 cells (as a negative control) were seeded in $3 \times 10^{6}$ cells $/ 21.5 \mathrm{ml} / 75 \mathrm{~cm}^{2}$ flask and $0.5 \mathrm{ml}$ of the culture supernatant were taken every day and quantity of the rboIL-2 was measured using IL-2 bovine ELISA Kit (Life Technologies) according to manufacture protocol. When higher concentration was desired, the rboIL-2 was concentrated using Amicon ${ }^{\circledR}$ Ultra-15 Centrifugal Filter Units (Merck Millipore Ltd., Co., Cork, Ireland). The R software (version 3.2.2, Vienna, Austria) was used for analyzing and visualizing quantitative data.

\section{CFSE proliferation assay}

The PBMC culture medium was composed as follow: the RPMI1640 medium (Gibco, Carlsbad, CA, USA) with 10\% FBS (HyClone), $50 \mu \mathrm{M}$ 2-mercaptethanol (Gibco), $50 \mu \mathrm{g} / \mathrm{ml}$ Gentamycin (Sigma-Aldrich), $10 \mathrm{mM}$ HEPES (Sigma-Aldrich) and 2 $\mathrm{mM}$ L-glutamine (Gibco). For CFSE proliferation assay, bovine PBMCs were stained with $10 \mathrm{ml}$ of $2.5 \mu \mathrm{M}$ CFSE (Invitrogen) for $10 \mathrm{~min}$ at $37^{\circ} \mathrm{C}$ and washed with the same volume of cold medium twice, and were served for the following assay. The CFSEstained PBMCs were stimulated with 3-fold serial dilutions of rboIL-2 starting at $10 \mathrm{ng} / \mathrm{ml}$, or with recombinant huIL-2 (rhuIL-2) (PeproTech, Cranbury, NJ, USA) starting at $100 \mathrm{ng} / \mathrm{ml}$, in $4 \times 10^{6}$ cells /well on a 24-wells plate for 5 days. The CFSE-stained PBMCs were similarly stimulated with $2 \mu \mathrm{g} / \mathrm{ml}$ of ConA for 5 days. After stimulation, the CFSE-stained PBMCs were incubated with anti-bovine CD3 monoclonal antibody (mAb) (MM1A, IgG1; Bio-Rad), anti-bovine CD4 mAb (CC8, IgG2a; Bio-Rad), anti-bovine CD8 mAb (CC63, IgG2a; Bio-Rad), anti-bovine WC1 mAb (CC15, IgG2a; Bio-Rad), or anti-bovine CD335 (NKp46) $\mathrm{mAb}$ (AKS1, IgG1; Bio-Rad) on ice and washed. Subsequently, the cells were stained with goat anti-mouse IgG PE-conjugated polyclonal antibody (abcam). After staining, the cells were further stained with 7-Aminoactinomycin D (Invitrogen) at $1 \mu \mathrm{g} / \mathrm{ml}$ for $10 \mathrm{~min}$ on ice to exclude dead cells and fixed with 1\% PFA/PBS solution until FACS analysis. The percentage of proliferated population $\left(\mathrm{CFSE}^{\text {low }}\right)$ in each cell surface marker was calculated as cell number of $\mathrm{CFSE}^{\text {low }}$ surface-marker ${ }^{+} /$total cell number within a lymphocyte gate. More than 30,000 cells in the lymphocyte population were analyzed for the CFSE-proliferation assay with a FACSCaliber flow cytometer and CELLQuest Software (BD Biosciences, San Jose, CA, USA).

\section{Responsiveness of a huIL-2 dependent human T-cell line to the rboIL-2}

The IL-2 dependent acute T-cell leukemia (ATL) cell line, ILT-Mat, was purchased from RIKEN cell bank and maintained in complete RPMI medium supplemented with $20 \mathrm{ng} / \mathrm{ml}$ of rhuIL-2. To examine whether or not rboIL-2 can replace rhuIL-2 for stimulating ILT-Mat cells, ILT-Mat cells were washed twice with the medium and cultured in complete RPMI medium supplemented with rboIL-2 (approximately $100 \mathrm{ng} / \mathrm{ml}$ ).

\section{Proliferation assay with rboIL-2/anti-boIL-2 mAb (rboIL-2/C5) complex}

The rboIL-2/C5 complex was generated by incubating rboIL-2 and anti-boIL-2 mAb (C5) (1:100 in mole ratio) for 10 min at room temperature. To examine the proliferative responses of PBMC to rboIL-2/C5 complex, the CFSE proliferation assay was performed as described above. The concentration of the rboIL-2/C5 complex, boIL-2, or anti-boIL-2 mAb (C5) were adjusted by diluting with HEK-293 culture supernatant.

\section{RESULTS}

\section{Stable expression of rboIL-2}

The boIL-2/piggyBac plasmid DNA was transfected into HEK-293 cells and puromycin ( $3 \mu \mathrm{g} / \mathrm{ml})$ was added from 2 days after transfection. The expression of rboIL-2 was confirmed by both GFP expression (data not shown) and Western blotting. For the Western blotting, the rboIL-2 band was located approximately at 17-20 kDa as predicted from the encoded amino acid sequence and previous reports [9, 24] (Fig. 1A). It appeared close to the size of the predicted native form with post-translational modification [13]. The rboIL-2 concentration in the culture supernatants gradually increased day by day and accumulated up to $330 \mathrm{ng} / \mathrm{ml}$ for 9 days (Fig. 1B). The culture supernatant on day 7 was routinely collected and stored until use, which generally contain about 100 $\mathrm{ng} / \mathrm{ml}$ of rboIL-2. After more than 24 passages, similar concentration of the rboIL-2 was maintained.

\section{Biological activity of the rboIL-2}

To assess biological activity of the rboIL-2, bovine PBMCs were stimulated with the rboIL-2 or rhuIL-2. The bovine PBMCs were stimulated with 9 serial dilutions of rboIL-2 from $10 \mathrm{ng} / \mathrm{ml}$ to $1.52 \mathrm{pg} / \mathrm{ml}$ or with rhuIL-2 from $100 \mathrm{ng} / \mathrm{ml}$ to $15.2 \mathrm{pg} / \mathrm{ml}$. The proliferative responses to each stimulation were analyzed using CFSE proliferation assay and presented as the percentages of the CFSE ${ }^{\text {low }}$ population in Fig. 2. The PBMCs proliferated with both rboIL-2 and rhuIL-2 in a comparatively dose-dependent manner, though rboIL-2 had higher activity than rhuIL-2 did even at lower concentrations. To understand what subsets of the PBMCs were responding to each stimulation, $\mathrm{CD} 3^{+} \mathrm{T}$ cells including $\mathrm{CD} 4^{+}, \mathrm{CD}^{+}$, and $\mathrm{WC}^{+} \mathrm{T}$ cell populations were analyzed (Fig. 2). Among the $\mathrm{CD} 3^{+} \mathrm{T}$ cell population, the $\mathrm{CD} 8^{+} \mathrm{T}$ cell population responded more strongly than the $\mathrm{CD} 4^{+} \mathrm{T}$ cell population did. It was obvious that the $\mathrm{CD}^{+}$and $\mathrm{WC}^{+} \mathrm{T}$ cell populations were lower responders compared with the $\mathrm{CD} 8^{+} \mathrm{T}$ cell population at the higher 
A

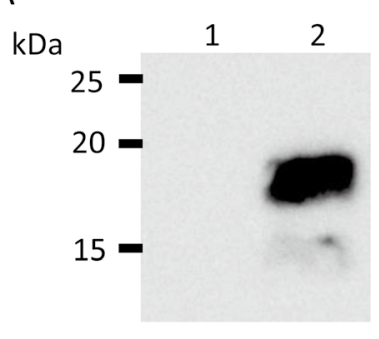

B

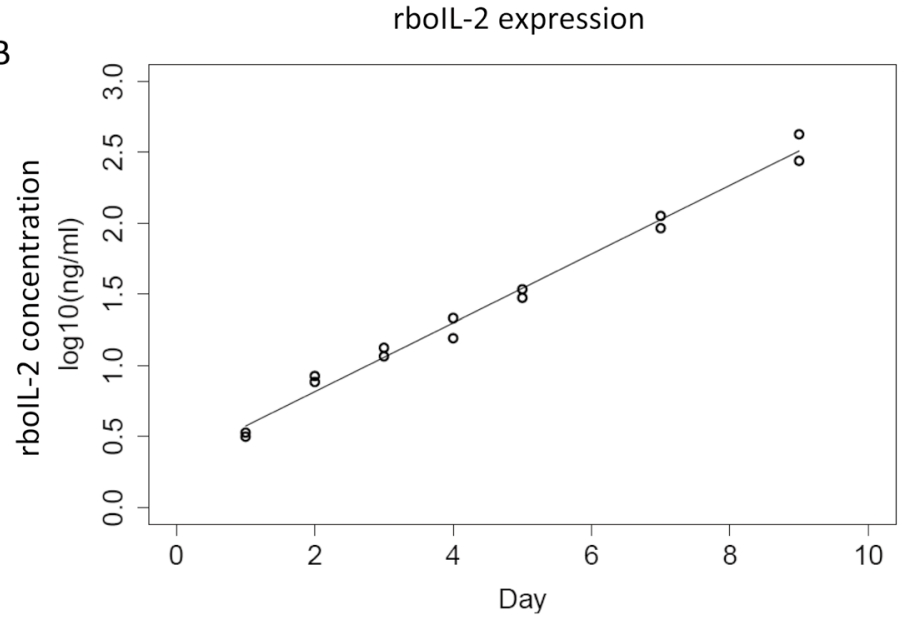

Fig. 1. The recombinant bovine interleukin 2 (rboIL-2) was expressed in the boIL-2/piggyBac transposed- and cloned- cell line. A: Western blotting with mouse anti-boIL-2 mAb (clone C5). Lane 1: Culture supernatant from HEK-293 cells and lane 2: Culture supernatant from the HEK-293/bolL-2 clone. The rboIL-2 band was located in $17 \mathrm{kDa}-20 \mathrm{kDa}$. B: The rboIL-2 concentration (Y-axis: $\log _{10}$ ) in the HEK-293/ boIL-2 clone cell culture supernatant were calculated using boIL-2 sandwich ELISA and plotted as concentration (ng/ml) of each day. Data shown is a representative of 2 independent experiments.

PBMC

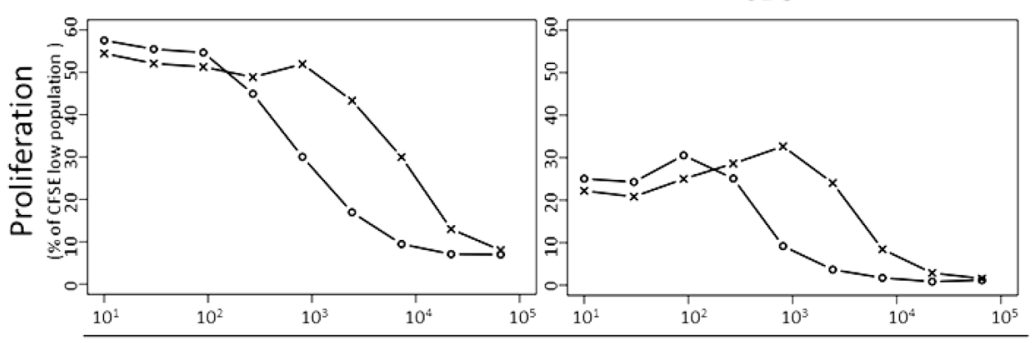

IL-2 dilution
$\mathrm{CD}^{+}$

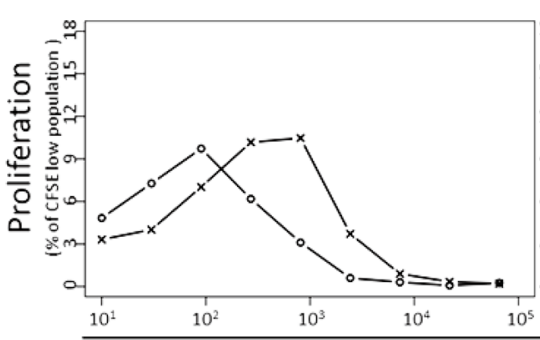

$\mathrm{CD} 8^{+}$

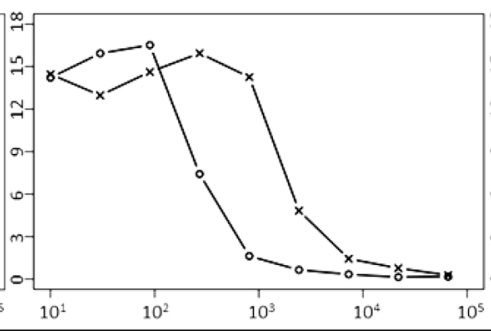

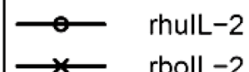

rbolL-2

\section{IL-2 dilution}

Fig. 2. Interleukin 2 (IL-2) titration on each subset in bovine peripheral blood mononuclear cells (PBMC). X-axis represent the fold of IL-2 dilution. $10^{1}$-fold dilution of recombinant human IL-2 (rhuIL-2) means $100 \mathrm{ng} / \mathrm{ml}$ of rhuIL-2, $10^{1}$-fold dilution of rboIL-2 means $10 \mathrm{ng} / \mathrm{ml}$ of rboIL-2. The marks (rhuIL-2: empty circle; rboIL-2: cross) indicate the proliferated cells of each $\mathrm{CD}^{+}, \mathrm{CD} 4^{+}, \mathrm{CD}^{+}$or $\mathrm{WC}^{+}$cell population. Data shown is a representative of 3 independent experiments.

concentrations $\left(0.37-10 \mathrm{ng} / \mathrm{ml}\right.$ of rboIL-2, $11.1-100 \mathrm{ng} / \mathrm{ml}$ of rhuIL-2). The $\mathrm{WC}^{+} \mathrm{T}$ cells that define a subpopulation of $\gamma \delta \mathrm{T}$ cell well responded to rboIL-2 similar to the $\mathrm{CD}^{+} \mathrm{T}$ cell population at $123 \mathrm{pg} / \mathrm{ml}$ but not to rhuIL-2. Overall, all cell populations examined proliferated strongly around $123 \mathrm{pg} / \mathrm{ml}$ for rboIL-2 and $11.1 \mathrm{ng} / \mathrm{ml}$ for rhuIL-2, though rhuIL-2 quickly reduced its activity after the peak.

\section{Proliferative responses to rboIL-2 and rhuIL-2}

To clarify whether bovine $\mathrm{T}$ cell populations had different proliferative responses with rboIL-2 and rhuIL-2, proliferation of each $\mathrm{T}$ cell population at the best stimulatory dose of each recombinant IL-2 (123 pg/ml for rboIL-2 and $11.1 \mathrm{ng} / \mathrm{ml}$ for rhuIL-2) were 


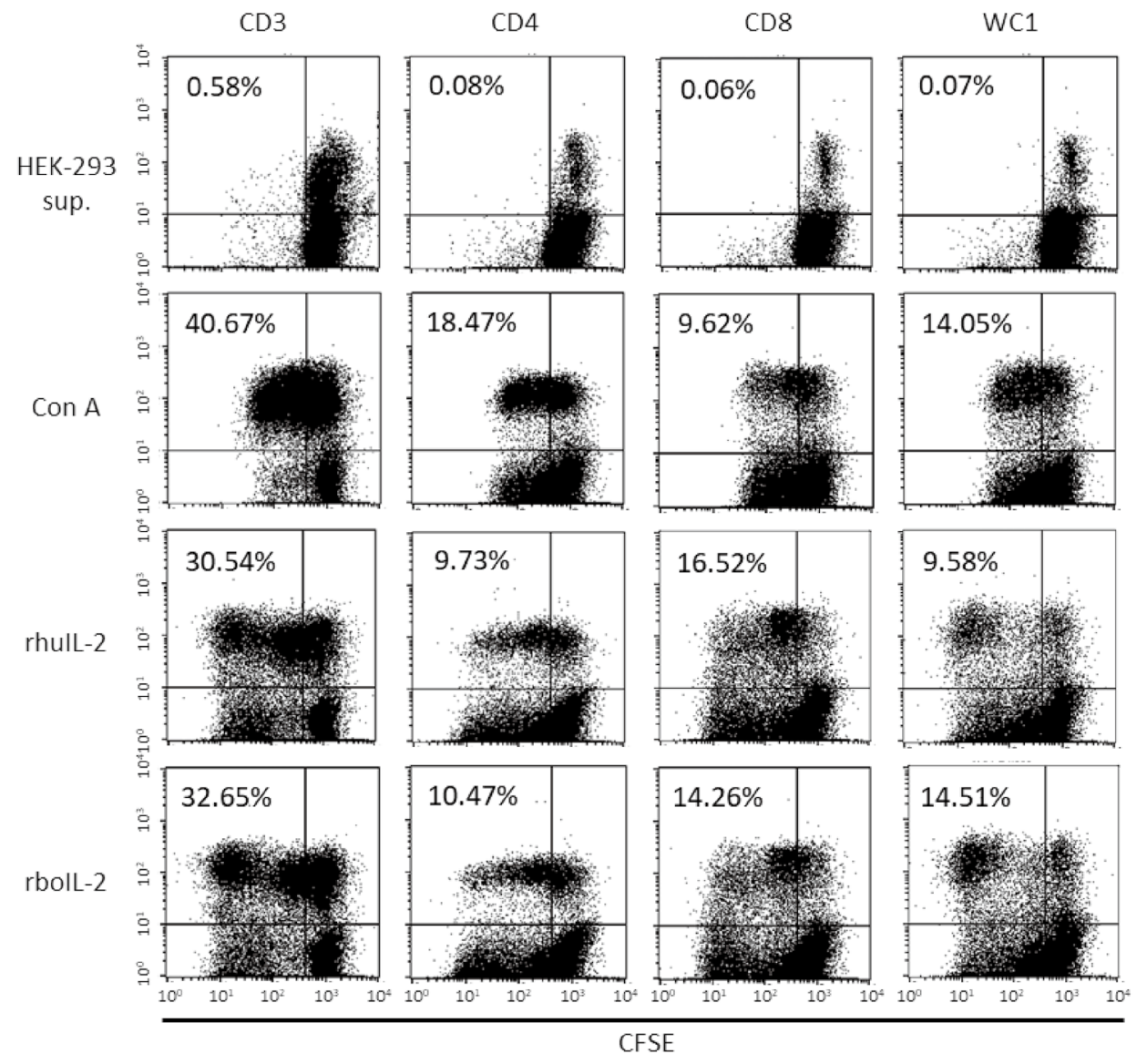

Fig. 3. Each T cell subset proliferation after culture with HEK-293 supernatant, $2 \mu \mathrm{g} / \mathrm{ml}$ of ConA, $11.1 \mathrm{ng} / \mathrm{ml}$ of recombinant human IL-2 (rhuIL-2) or $123 \mathrm{pg} / \mathrm{ml}$ of recombinant bovine interleukin 2 (rbolL-2). The populations of proliferated each cell (carboxyfluorescein diacetate succinimidyl ester $(\mathrm{CFSE})^{\text {low }}$ of $\mathrm{CD}^{+}, \mathrm{CD}^{+}, \mathrm{CD}^{+}$or $\mathrm{WC1}^{+}$cells) were shown upper left of individual dot plots. $\mathrm{X}$-axis indicates CFSE staining. Y-axis represents the expression of individual $\mathrm{T}$ cell subsets. The percentage on the individual plots represent proliferated the CFSE ${ }^{\text {low }}$ subsets. Data shown is a representative of more than 3 independent experiments.

compared as shown in Fig. 3. As expected, a T cell mitogen, ConA (Invitrogen), stimulated CD4 ${ }^{+} \mathrm{T}$ cell population better than $\mathrm{CD}^{+} \mathrm{T}$ cell population. Interestingly, rhuIL-2 stimulated more $\mathrm{CD} 8^{+} \mathrm{T}$ cell population than $\mathrm{CD} 4^{+}$or $\mathrm{WC}^{+} \mathrm{T}$ cell population.

\section{Proliferative effect of rbolL-2 on a hulL-2-dependent T cell line}

The ILT-Mat cell line was used to examine whether or not the rboIL-2 could maintain a huIL-2 dependent human T-cell line. Although lower concentration of rboIL-2 could not maintain the ILT-Mat cell line, $100 \mathrm{ng} / \mathrm{ml}$ of rboIL-2 could maintain the cell line up to 12 passages (further passages have not been tested).

\section{Biological activity of rboIL-2/C5 complex}

Because anti-IL-2 antibodies can selectively expand a certain population of IL-2-responsive cells, biological activity of a rboIL-2/C5 complex was examined using CFSE proliferation assay. As shown in Fig. 4, when rboIL-2 (123 pg/ml) was added, $\mathrm{CD}^{+} \mathrm{T}$ cell population was well proliferated to $18.52 \%$ as compared with HEK-293 supernatant alone to $0.77 \%$. Since the same amount of HEK-293 supernatant in rboIL-2 was added, possible inhibitory effect of the supernatant was excluded. By adding rboIL-2/C5 complex, $\mathrm{CD}^{+} \mathrm{T}$ cell population increased to $19.69 \%$ similarly in response to rboIL-2. Regarding cell populations in response to rbolL-2/C5 complex, it was noticeable that there was increased $\mathrm{CD}^{-}$cell population. When $\mathrm{CD} 4^{+}, \mathrm{CD} 8^{+}$, and $\mathrm{WC1}^{+} \mathrm{T}$ cell population were examined, these populations responded to both rbolL-2 and rboIL-2/C5 complex similarly except $\mathrm{CD}^{+} \mathrm{T}$ cell population which responded more to rbolL-2 and rboIL-2/C5 complex. To examine $\mathrm{CD} 3^{-}$cell population, the bovine NKp46 molecule representing NK cell surface markers was added to the CFSE proliferation assay analysis. As shown Fig. 4, the $\mathrm{NKp} 46^{+}$cell population strongly responded to rboIL-2/C5 complex, increasing to $8.45 \%$ as compared to $1.5 \%$ with rboIL-2 alone. Overall, $\mathrm{CD} 8^{+} \mathrm{T}$ and $\mathrm{NKp} 46^{+}$cell populations were good responders for rboIL-2/C5 complex. 


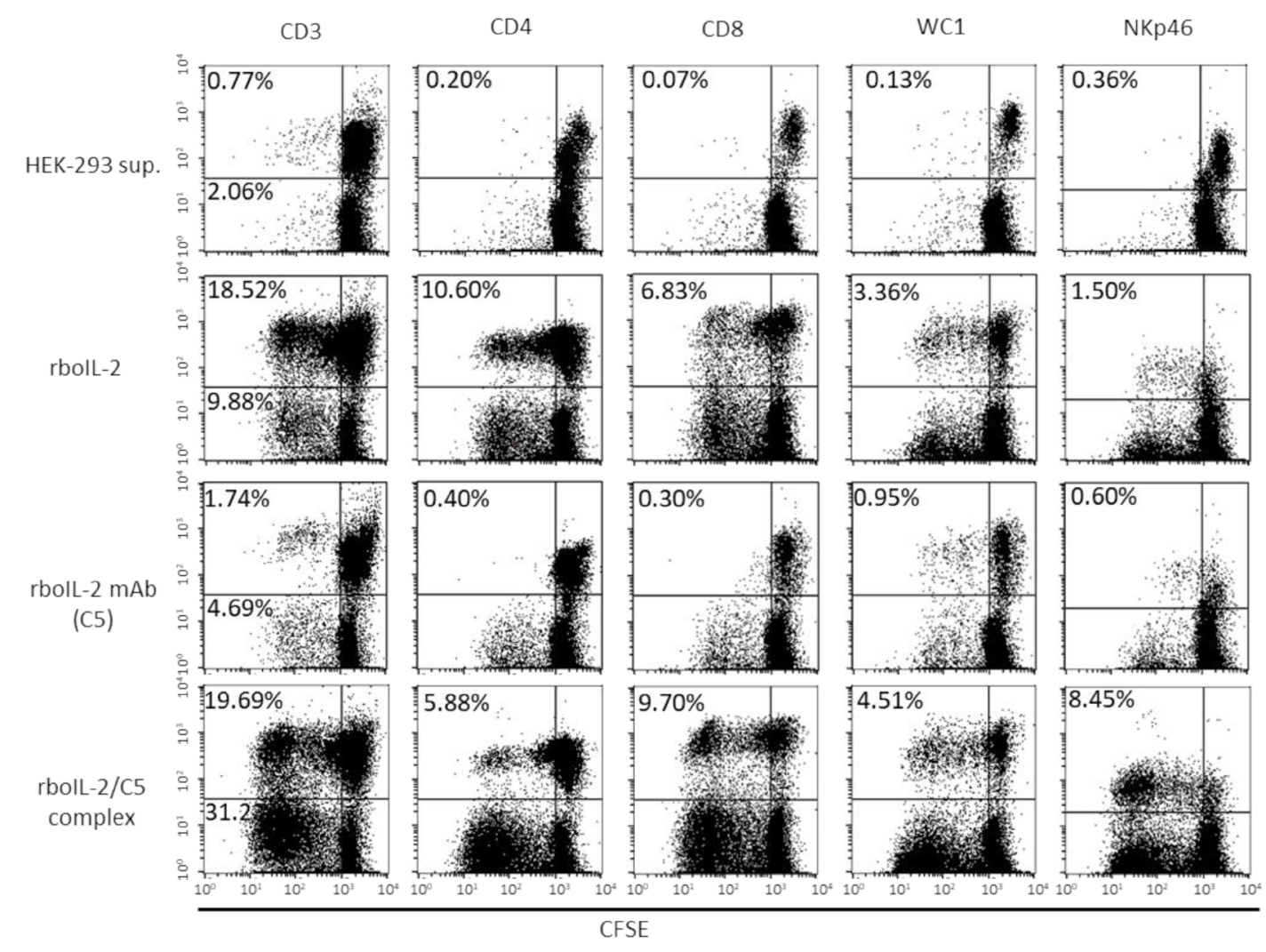

Fig. 4. The recombinant bovine interleukin 2 (rbolL-2)/C5 complex induces $\mathrm{CD} 8^{+} \mathrm{T}$ cell and $\mathrm{NKp} 46^{+}$cell proliferation. Carboxyfluorescein diacetate succinimidyl ester (CFSE) proliferation assay on the results of peripheral blood mononuclear cells (PBMC) cultivation for 5 days with HEK-293 culture supernatant., $0.25 \mathrm{ng} / \mathrm{ml}$ of rboIL-2, $100 \mathrm{ng} / \mathrm{ml}$ of anti-boIL-2 mAb (clone C5), or rboIL-2/C5 complex. X-axis represent intensity of CFSE. Y-axis means individual PE-labeled lymphocyte subsets $\left(\mathrm{CD}^{+}, \mathrm{CD}^{+}, \mathrm{CD} 8^{+}, \mathrm{WC1}^{+}\right.$or $\left._{\mathrm{NKp} 46^{+}} \mathrm{cells}\right)$. The percentages on the individual panels represent the $\mathrm{CFSE}^{\text {low }}$ subsets. Data shown is a representative of 2 independent experiments.

\section{DISCUSSION}

IL-2 is an important modulator for balancing activation of effector immune cells and Treg cells. Studies of boIL-2 began in 1980's starting with purification of biologically active boIL-2 from ConA-stimulated PBMC [9, 24]. The mature boIL-2 consists of 135 amino acids and has $65 \%$ identity with huIL-2 [10]. It has been known that huIL-2 could stimulate and maintain bovine T cells, though it didn't stimulate NK cells [14]. Therefore, commercially available huIL-2 was often used for immunological experiments for bovine systems.

We have established the boIL-2-expressing mammalian cell line, HEK-293/boIL-2, and verified the stimulatory activity of its supernatant for PBMCs and $\mathrm{CD}^{+}{ }^{+} \mathrm{T}$ cell populations. The rboIL-2 also strongly stimulated $\mathrm{NKp} 46^{+}$cell population when added as the rbolL-2/C5 complex. The recombinant IL-2 is a useful immunological tool and allow us to study its activities and to maintain $\mathrm{T}$ cells for an extended period. The rboIL-2 was first produced in E. coli and yeast [4, 10, 27, 33]. Further, rboIL-2 was generated by baculovirus expression system and shown to enhance bovine PBMC proliferation [11, 19]. Transient mammalian expression systems were also often used to express rboIL-2 and successfully applied to many immunological assays in bovine system [8, 13]. Although all these rboIL-2s have shown some stimulatory activities, the structures that reflect activity of boIL-2 are slightly different depending on whether or not the expressed protein is glycosylated [21,31]. To maintain native activity of boIL-2, correct post-translational modification should be also taken account. In this regard, it is reasonable to use mammalian cell lines to produce boIL-2 since human IL-2 generated in BHK, HeLa, or CHO cells was $O$-glycosylated, similar to the protein secreted from natural T cells [13]. For a continual need of such a boIL-2, a stable expression of boIL-2 in mammalian cells is therefore advantageous. In this study, the piggyBac transposon system was used to introduce boIL-2 gene to HEK-293 cells. The sustainable cell line with stable expression of boIL-2 was established after cloning by limiting dilution. Because it is secreted, harvesting and storing the culture supernatant at the time of passage can provide sufficient amount of active bolL- 2 .

Stimulatory activities of the rboIL- 2 were varied among $\mathrm{CD}^{+} \mathrm{T}$ cells including $\mathrm{CD} 4^{+}, \mathrm{CD} 8^{+}, \mathrm{WC}^{+} \mathrm{T}$ cells. The differences of activities observed among these cells were most likely due to the level of expression of each IL-2R subunit on each cell population. The IL-2R consists of three subunits: IL-2R $\alpha$ (CD25), IL-2R $\beta$ (CD122), and c $\gamma$ (CD132) chains [27]. The IL-2R with high affinity requires all three chains (trimer), while the one with intermediate affinity is a heterodimer of IL-2R $\beta$ and $c \gamma$ chains. Although both IL-2R $\beta$ and $c \gamma$ chains have activation signal motifs in their cytoplasmic domains, the IL-2R $\alpha$ chain has a short cytoplasmic 
tail and lacks such a signal motif, and therefore does not deliver signals [23, 25]. It is known that the balance in expression of each chain can determine how the target cells respond. The most of $\mathrm{CD}^{+} \mathrm{T}$ cell population constitutively express all three IL-2R subunits but at different level. For example, Treg cells in the CD4 ${ }^{+} \mathrm{T}$ cell population highly express its signature molecule, $\mathrm{CD} 25$, on the cell surface and respond to a small amount of IL-2, suppressing effector T cells. On the other hand, most of CD8 ${ }^{+} \mathrm{T}$ cells preferentially express the IL-2R $\beta / \mathrm{c} \gamma$ heterodimer with intermediate affinity and require higher dose of IL-2 for their activation. In the present study, the bovine $\mathrm{CD}^{+} \mathrm{T}$ cell population well responded to ConA stimulation as expected but less responded to both rboIL-2 and rhuIL-2 compared to other cell populations. This may not be surprising since this population may contain Treg cells that could suppress effector T cells. Treg cells is sensitive to a small amount of IL-2 and demonstrate inhibitory effects by the competitive removal of IL-2 from $\mathrm{CD}^{+} \mathrm{T}$ cells [22]. Since $\mathrm{WC1}^{+}$cells also play a regulatory role for effector cells [16], explanation of stimulatory effects using PBMC in vitro became more complicated in cattle. However, we speculate that adding rboIL-2 above threshold may overcome the Treg-cell inhibitory effects. The bovine $\mathrm{CD} 8^{+} \mathrm{T}$ cell population proliferated with both rboIL-2 and rhuIL-2 in higher dose. The rhuIL-2 appeared active only in higher concentration for bovine CD8 ${ }^{+} \mathrm{T}$ cell population, suggesting that rhuIL-2 has lower affinity to bovine IL-2R even if to the trimer and thus requires higher dose compared with rboIL-2 to stimulate bovine cells. And vice versa, the rboIL-2 was able to maintain huIL-2-dependent human T cell line, ILT-Mat, but only in a high concentration $(100 \mathrm{ng} / \mathrm{ml})$, indicating that the rboIL-2 has lower affinity to human IL-2R. As described earlier, the identity of amino acid sequence between boIL-2 and huIL-2 is $65 \%$ and they are interchangeable for T cell activation to some extent. Similarly, huIL-2 has 57\% identity with mouse IL-2, yet stimulates mouse IL-2Rs whereas mouse IL-2 binds rather weakly to huIL-2Rs [2]. Although 3D structure of the quaternary IL-2/IL-2R complex has been defined, it is difficult to address how those differences in their amino acid sequences and structures influence the biological activities [3]. The $\mathrm{WC1}^{+} \mathrm{T}$ cell population, a major subset of $\gamma \delta \mathrm{T}$ cells, appears to have an intermediate responsiveness in between $\mathrm{CD} 4^{+}$and $\mathrm{CD} 8^{+} \mathrm{T}$ cell populations to stimuli with ConA, rhuIL-2, and rboIL-2.

Subtle changes of the structure in the IL-2 molecule alter interaction with the IL-2R, delivering different signals and thus selectively differentiating target subsets [6]. In mice, two different mAbs, JES6-1 and S4B6, specific to mouse IL-2 could selectively expand opposing cell types, Treg cells and effector T cells respectively by complexing with mouse IL-2 [6]. The C5 is a boIL-2-specific mAb and confirmed its specificity to the rboIL-2 produced in this study. After validating bioactivity of the rboIL-2, we examined what subset of $\mathrm{T}$ cells could expand with the rbolL-2/C5 complex. Among CD $3^{+} \mathrm{T}$ cells, CD8 ${ }^{+} \mathrm{T}$ cells expanded better with rboIL-2/C5 complex than rboIL-2, while $\mathrm{CD}^{+} \mathrm{T}$ cells expanded better with rboIL-2 than rboIL-2/C5 complex. This may suggest that mAb C5 binds an epitope where the boIL-2 has contact with boIL-2R $\alpha$ chain and therefore blocking their interaction, leading to a preferential stimulation of the boIL-2R $\beta / \mathrm{c} \gamma$ heterodimer-bearing $\mathrm{T}$ cells such as $\mathrm{CD} 8^{+} \mathrm{T}$ cells. However, IL-2 antibody binding may not simply block the specific site but also alter IL-2 half-life or could induce conformational change that altered IL-2 binding to the IL-2R [6]. In this experiment, it was noticeable that CD3- cells population obviously expanded better with rboIL-2/C5 complex (31.23\%) than with rboIL-2 (9.88\%). This prompted us to examine bovine NK cells, NKp46 ${ }^{+}$cells, for their expansion because bovine NK cells reportedly propagate with boIL-2 $[8,30]$. The NKp46 ${ }^{+}$cell expanded with rboIL-2/ C5 complex better than rboIL-2 alone, as shown $8.45 \%$ and $1.5 \%$ in expanded population respectively. It is reported that the $\mathrm{CD} 25^{\text {low }} \mathrm{NK}$ cells were the predominant subset of NK cells within the peripheral blood [17]. We also speculate that the CD3 cell population may also include $\mathrm{NKp} 46^{+}$and NKp46 ILCs [18]. Considering NKp46 ${ }^{+} \mathrm{CD}^{+}$cells [12], significant number of $\mathrm{NKp} 46^{+}$cells appears to respond to rbolL-2/C5 complex.

In this study, the mammalian cell line stably expressing boIL-2 was established and its activity was evaluated. We have recently used this rboIL-2 for bovine $\mathrm{CD}^{+} \mathrm{T}$ cell propagation in vitro and successfully identified $\mathrm{CD} 4^{+} \mathrm{T}$ cell epitopes on structural proteins on bovine leukemia virus (data not shown) using tetramer-guided epitope mapping methods [26]. The rboIL-2 is a useful immunological tool not just as a T cell growth factor but also capable of expand a variety of immune cells. Further, the rboIL-2/C5 complex could function as an IL-2 agonist that selectively increases the NK cell population or ILCs, which in turn could clinically be used to enhance the activity of NK cells. More anti-boIL-2 mAbs need to be investigated. Modification of boIL-2 is a unique way of creating a biological molecule to either stimulate or regulate immune cells by targeting a specific cell. Detailed expression profiles of boIL-2R subunits on each boIL-2-responsive cell need to be clarified to understand how modification of boIL-2 affects cell signaling and selection of immune cells.

CONFLICT OF INTEREST. The authors declare no competing interests exist.

ACKNOWLEDGMENTS. We thank Yukari Kawagoe for the technical assistance of Flow cytometry. This study was supported in part by JSPS KAKEN Grant no. 19H03128.

\section{REFERENCES}

1. Abbas, A. K., Trotta, E., R Simeonov, D., Marson, A. and Bluestone, J. A. 2018. Revisiting IL-2: Biology and therapeutic prospects. Sci. Immunol. 3: eaat1482. [Medline] [CrossRef]

2. Arenas-Ramirez, N., Woytschak, J. and Boyman, O. 2015. Interleukin-2: Biology, design and application. Trends Immunol. 36: 763-777. [Medline] [CrossRef]

3. Arkin, M. R., Randal, M., DeLano, W. L., Hyde, J., Luong, T. N., Oslob, J. D., Raphael, D. R., Taylor, L., Wang, J., McDowell, R. S., Wells, J. A. and Braisted, A. C. 2003. Binding of small molecules to an adaptive protein-protein interface. Proc. Natl. Acad. Sci. USA 100: $1603-1608$. 
[Medline] [CrossRef]

4. Baker, P. E. 1987. Bovine interleukin 2: cloning, high level expression, and purification. Vet. Immunol. Immunopathol. 17: 193-209. [Medline] [CrossRef]

5. Blattman, J. N., Grayson, J. M., Wherry, E. J., Kaech, S. M., Smith, K. A. and Ahmed, R. 2003. Therapeutic use of IL-2 to enhance antiviral T-cell responses in vivo. Nat. Med. 9: 540-547. [Medline] [CrossRef]

6. Bluestone, J. A., Crellin, N. and Trotta, E. 2015. IL-2: Change structure ... Change function. Immunity 42: 779-781. [Medline] [CrossRef]

7. Boyman, O., Kovar, M., Rubinstein, M. P., Surh, C. D. and Sprent, J. 2006. Selective stimulation of T cell subsets with antibody-cytokine immune complexes. Science 311: 1924-1927. [Medline] [CrossRef]

8. Boysen, P., Olsen, I., Berg, I., Kulberg, S., Johansen, G. M. and Storset, A. K. 2006. Bovine CD2-/NKp46 ${ }^{+}$cells are fully functional natural killer cells with a high activation status. BMC Immunol. 7: 10. [Medline] [CrossRef]

9. Brown, W. C. and Grab, D. J. 1985. Biological and biochemical characterization of bovine interleukin 2. Studies with cloned bovine T cells. $J$. Immunol. 135: 3184-3190. [Medline]

10. Cerretti, D. P., McKereghan, K., Larsen, A., Cantrell, M. A., Anderson, D., Gillis, S., Cosman, D. and Baker, P. E. 1986. Cloning, sequence, and expression of bovine interleukin 2. Proc. Natl. Acad. Sci. USA 83: 3223-3227. [Medline] [CrossRef]

11. Collins, R. A., Tayton, H. K., Gelder, K. I., Britton, P. and Oldham, G. 1994. Cloning and expression of bovine and porcine interleukin-2 in baculovirus and analysis of species cross-reactivity. Vet. Immunol. Immunopathol. 40: 313-324. [Medline] [CrossRef]

12. Connelley, T. K., Longhi, C., Burrells, A., Degnan, K., Hope, J., Allan, A. J., Hammond, J. A., Storset, A. K. and Morrison, W. I. 2014. NKp46 $\mathrm{CD}^{+}$cells: a novel nonconventional T cell subset in cattle exhibiting both NK cell and T cell features. J. Immunol. 192: 3868-3880. [Medline] [CrossRef]

13. Conradt, H. S., Nimtz, M., Dittmar, K. E. J., Lindenmaier, W., Hoppe, J. and Hauser, H. 1989. Expression of human interleukin-2 in recombinant baby hamster kidney, Ltk-, and Chinese hamster ovary cells. Structure of O-linked carbohydrate chains and their location within the polypeptide. $J$. Biol. Chem. 264: 17368-17373. [Medline]

14. Endsley, J. J., Endsley, M. A. and Estes, D. M. 2006. Bovine natural killer cells acquire cytotoxic/effector activity following activation with IL12/15 and reduce Mycobacterium bovis BCG in infected macrophages. J. Leukoc. Biol. 79: 71-79. [Medline] [CrossRef]

15. Gillis, S. 1983. Interleukin 2: biology and biochemistry. J. Clin. Immunol. 3: 1-13. [Medline] [CrossRef]

16. Guzman, E., Hope, J., Taylor, G., Smith, A. L., Cubillos-Zapata, C. and Charleston, B. 2014. Bovine $\gamma \delta \mathrm{T}$ cells are a major regulatory T cell subset. J. Immunol. 193: 208-222. [Medline] [CrossRef]

17. Hamilton, C. A., Mahan, S., Bell, C. R., Villarreal-Ramos, B., Charleston, B., Entrican, G. and Hope, J. C. 2017. Frequency and phenotype of natural killer cells and natural killer cell subsets in bovine lymphoid compartments and blood. Immunology 151: 89-97. [Medline] [CrossRef]

18. Ivanova, D. L., Denton, S. L., Fettel, K. D., Sondgeroth, K. S., Munoz Gutierrez, J., Bangoura, B., Dunay, I. R. and Gigley, J. P. 2019. Innate lymphoid cells in protection, pathology, and adaptive immunity during apicomplexan infection. Front. Immunol. 10: 196. [Medline] [CrossRef]

19. Kashima, T., Iwata, H. and Inoue, T. 1999. Expression of bovine interleukin-2 in insect cells by recombinant baculovirus. J. Vet. Med. Sci. 61: 705-707. [Medline] [CrossRef]

20. Kühnle, G., Collins, R. A., Scott, J. E. and Keil, G. M. 1996. Bovine interleukins 2 and 4 expressed in recombinant bovine herpesvirus 1 are biologically active secreted glycoproteins. J. Gen. Virol. 77: 2231-2240. [Medline] [CrossRef]

21. Ma, B., Guan, X., Li, Y., Shang, S., Li, J. and Tan, Z. 2020. Protein glycoengineering: an approach for improving protein properties. Front Chem. 8: 622. [Medline] [CrossRef]

22. McNally, A., Hill, G. R., Sparwasser, T., Thomas, R. and Steptoe, R. J. 2011. CD4 $4^{+}$CD $25^{+}$regulatory T cells control CD8 ${ }^{+}$T-cell effector differentiation by modulating IL-2 homeostasis. Proc. Natl. Acad. Sci. USA 108: 7529-7534. [Medline] [CrossRef]

23. Nakamura, Y., Russell, S. M., Mess, S. A., Friedmann, M., Erdos, M., Francois, C., Jacques, Y., Adelstein, S. and Leonard, W. J. 1994. Heterodimerization of the IL-2 receptor $\beta$ - and $\gamma$-chain cytoplasmic domains is required for signalling. Nature 369: 330-333. [Medline] [CrossRef]

24. Namen, A. E. and Magnuson, J. A. 1984. Production and characterization of bovine interleukin-2. Immunology 52: 469-475. [Medline]

25. Nelson, B. H., Lord, J. D. and Greenberg, P. D. 1994. Cytoplasmic domains of the interleukin-2 receptor beta and gamma chains mediate the signal for T-cell proliferation. Nature 369: 333-336. [Medline] [CrossRef]

26. Novak, E. J., Liu, A. W., Gebe, J. A., Falk, B. A., Nepom, G. T., Koelle, D. M. and Kwok, W. W. 2001. Tetramer-guided epitope mapping: rapid identification and characterization of immunodominant $\mathrm{CD} 4^{+} \mathrm{T}$ cell epitopes from complex antigens. J. Immunol. 166: 6665-6670. [Medline] [CrossRef]

27. Patil, A. A., Saini, M., Sharma, S., Bind, R. B. and Gupta, P. K. 2005. Cloning and expression of bovine (Bos indicus) interleukin-2 in Escherichia coli. Indian J. Biotechnol. 4: 88-92.

28. Peest, D., Leo, R. and Deicher, H. 1995. Tumor-directed cytotoxicity in multiple myeloma — the basis for an experimental treatment approach with interleukin 2. Stem Cells 13 Suppl 2: 72-76. [Medline]

29. Spolski, R., Li, P. and Leonard, W. J. 2018. Biology and regulation of IL-2: from molecular mechanisms to human therapy. Nat. Rev. Immunol. 18: 648-659. [Medline] [CrossRef]

30. Storset, A. K., Kulberg, S., Berg, I., Boysen, P., Hope, J. C. and Dissen, E. 2004. NKp46 defines a subset of bovine leukocytes with natural killer cell characteristics. Eur. J. Immunol. 34: 669-676. [Medline] [CrossRef]

31. Voshol, H., Dullens, H. F., Den Otter, W. and Vliegenthart, J. F. 1996. The glycosylation profile of interleukin-2 activated human lymphocytes correlates to their anti-tumor activity. Anticancer Res. 16: 155-159. [Medline]

32. Wakasugi, H., Bertoglio, J., Tursz, T. and Fradelizi, D. 1985. IL 2 receptor induction on human T lymphocytes: role for IL 2 and monocytes. $J$. Immunol. 135: 321-327. [Medline]

33. Wedlock, D. N., Doolin, E. E., Parlane, N. A., Lacy-Hulbert, S. J., Woolford, M. W. and Buddle, B. M. 2000. Effects of yeast expressed recombinant interleukin-2 and interferon-gamma on physiological changes in bovine mammary glands and on bactericidal activity of neutrophils. J. Dairy Res. 67: 189-197. [Medline] [CrossRef]

34. Wyckoff, J. H. 3rd., Howland, J. L., Scott, C. M. O. C., Smith, R. A. and Confer, A. W. 2005. Recombinant bovine interleukin 2 enhances immunity and protection induced by Brucella abortus vaccines in cattle. Vet. Microbiol. 111: 77-87. [Medline] [CrossRef] 